УДК 612.135-057.87

DOI https://doi.org/10.26661/2410-0943-2020-1-07

\title{
Особливості гемодинаміки у пубертатний та постпубертатний етапи онтогенезу людини
}

\author{
Станішевська Т. І., Горна О. І., Горбань Д. Д. \\ ORCID: 0000-0002-4012-7335 \\ Мелітопольський державний педагогічний університет імені Богдана Хмельнищького \\ horban_daria@mdpu.org.ua
}

\section{Ключові слова:}

мікрочииркуляиія крові, лазерна допплерівська флоуметрія, вікові періоди онтогенезу.
Стаття присвячена вивченню особливостей вікової динаміки індивідуально-типологічних показників мікроциркуляції крові на пубертатному і постпубертатному періодах розвитку організму людини. Дослідження проводилися на базі лабораторії фізіологічних досліджень. У дослідженні взяли участь 63 умовно здорові досліджувані за добровільною згодою віком 14-15 та 18-19 років. 3 метою вивчення функціонального стану мікроциркуляції крові в організмі людини був використаний метод лазерної допплерівської флоуметрії. В осіб чоловічої та жіночої статей на вивченому етапі онтогенезу спостерігали збереження гетерохронності за величинами параметрів мікроциркуляції крові та середнього квадратичного відхилення тканинного кровотоку. Так, на одному віковому відрізку були вищими показники у досліджуваних жіночої статі, а на іншому - в осіб чоловічої статі. Середні величини показників мікроциркуляції крові у хлопців та дівчат одного віку достовірно не відрізнялися. Комп'ютерна програма обробки дозволяла визначити такі характеристики мікроциркуляції, як: параметр мікроциркуляції, середнє квадратичне відхилення реєстрованих допплерівських сигналів та коефіцієнт варіації. В обстежених пубертатного та постпубертатного віку обох статей виявлено три типи мікроциркуляції. Аперіодична ЛДФ-грама відповідала нормоемічному типу мікроциркуляції крові, що характеризується збалансованістю механізмів вазомоторної, метаболічної та нейрогенної регуляції мікроциркуляції за частотою і амплітудою. Для синусоїдальної ЛДФ-грами, що відповідає гіпоемічному типу мікроциркуляції крові, характерний низький показник параметру мікроциркуляції, зумовлений зниженням вазомоторних механізмів у регуляції. Монотонна ЛДФ-грама гіперемічного типу характеризувалася високим параметром мікроциркуляції, переважанням пасивних механізмів, дихальних і серцевих ритмів у регуляції мікроциркуляції. Частота співвідношення різних мікроциркуляторних типів приблизно однакова у осіб жіночої та чоловічої статі і безпосередньо залежить від їхнього віку. 


\title{
Features of hemodynamics in pubertal and postpubertal stages of human ontogenesis
}

\author{
Stanishevska T. I., Gorna O. I., Horban D. D. \\ Melitopol Bogdan Khmelnytsky State Pedagogical University
}

Key words: microcirculation of blood, laser Doppler flowmetry, age periods of ontogenesis.

\begin{abstract}
The article is devoted to the study of the features of age-related dynamics of individual-typological indicators of blood microcirculation in the pubertal and post-pubertal periods of human body development. The study has been carried out in the laboratory of physiological research and included 63 relatively healthy people on the voluntary consent in age of 14-15 and 18-19 years old. In order to study the functional state of blood microcirculation in the human body, the method of Laser Doppler flowmetry was used. In both sexes, at the studied stage of ontogenesis, heterochromicity was observed in the values of blood microcirculation parameters and the average square deviation of tissue blood flow. So, at one age segment, the indicators were higher in the females, and at the other - in males. The average values of blood microcirculation indicators in boys and girls of the same age did not significantly differ. The computer processing program made it possible to determine the following microcirculation characteristics: the microcirculation parameter, the average square deviation of the recorded Doppler signals, and the coefficient of variation. In the examined pubertal and post-pubertal ages of both sexes, three types of microcirculation were found. The aperiodic LDF-gram corresponded to the normoemic type of blood microcirculation, characterized by a balanced mechanism of vasomotor, metabolic and neurogenic regulation of microcirculation in frequency and amplitude. The sinusoidal LDF-gram, which corresponds to the hypoemic type of blood microcirculation, characterized by a low indicator of the microcirculation parameter due to a decrease in vasomotor mechanisms in regulation. The monotonous LDF-gram of the hyperemic type was characterized by a high microcirculation parameter, the predominance of passive mechanisms, respiratory and cardiac rhythms in the regulation of microcirculation. The frequency of the ratio of different microcirculatory types is approximately the same in women and men directly depends on their age.
\end{abstract}

\section{Вступ}

Однією з важливих медико-біологічних проблем $\epsilon$ вивчення окремих етапів зростаючого організму в постнатальному онтогенезі. Суттєве значення у вивченні закономірностей морфо-функціонального розвитку має використання методології вікової періодизації. $€$ думка ${ }^{1,2}$ про те, що підвищена сенситивність виникає, як правило, під час переходу від одного вікового періоду до іншого.

Для вікової фізіології вивчення проблеми мікроциркуляції являє певний інтерес, оскільки дозволяє розкрити механізми, які лежать в основі пристосувальних реакцій організму. Для розуміння місця і ролі гемомікроциркуляції у підтримці тканинного гомеостазу ключове значення має аналіз становлення в онтогенезі дефінітивних конструкцій мікроциркуляторного русла i механізмів регуляції капілярного кровотоку. За даними літератури ${ }^{1,3,4}$, найбільш активно перебудова системи мікроциркуляції відбувається на етапах пубертатного і постпубертатного періодів розвитку організму людини.

Своєрідність функціонування мікросудин, ïх висока реактивність, специфіка організації, велика поширеність і тісна близькість 3 тканинними елементами органів - все це зумовлює той факт, що вони являють собою найбільшу лабільну ланку у серцево-судинній системі і є об'єктом постійного дослідження.

Дослідження системи мікроциркуляції крові у дітей ${ }^{1-4}$ у постнатальному онтогенезі являють великий науковий і практичний інтерес. Завдяки останнім досягненням комп'ютерних технологій у галузі спектрального аналізу коливань кровотоку мікросудинного русла і розробці адекватних функціональних проб стало можливим неінвазивно за допомогою лазерної допплерівської флоуметрії (ЛДФ) виділити і проаналізувати регуляторні фактори, контролюючі мікрогемодинаміку у віковому аспекті. 
Таким чином, метою нашого дослідження був аналіз вікової динаміки показників мікроциркуляції крові на пубертатному і постпубертатному періодах розвитку організму людини.

\section{Матеріали та методи}

Дослідження проводилися на базі лаборатоpiї фізіологічних досліджень Мелітопольського педагогічного університету імені Богдана Хмельницького. У дослідженні взяли участь 63 майже здорові досліджувані за добровільною згодою віком 14-15 (учні загальноосвітніх шкіл міста Мелітополя) та 18-19 років (студенти МДПУ імені Богдана Хмельницького). 3 них 33 дівчини та 30 хлопців-добровольців. Дослідження проводилися відповідно до сучасних вимог біоетики.

3 метою вивчення функціонального стану мікроциркуляції крові в організмі людини був використаний метод лазерної допплерівської флоуметрії (ЛДФ), що дозволяло оцінити стан тканинного кровотоку і виявити ознаки зміни мікроциркуляції під впливом різних чинників.

ЛДФ здійснювали лазерним аналізатором кровотоку «ЛАКК-01» 3 лазерним джерелом випромінювання на довжині хвилі 0,63 мкм. Лазерний аналізатор був з'єднаний із комп'ютером. Дослідження стану мікроциркуляції проводили у досліджуваних у сидячому стані. Голівка оптичного зонду (датчика приладу) фіксувалась на вентральній поверхні 4-го пальця лівої руки; рука розташовувалась на рівні серця. Тривалість стандартного запису становила 3 хвилини у першій половині дня. Записи ЛДФ-грам робилися відповідно до методичних рекомендацій «Методика лазерної допплерівської флоуметрії» ${ }^{5-8}$. Комп'ютерна програма обробки ЛДФ-грами дозволяла визначити такі характеристики мікроциркуляції, як: ПМ - параметр мікроциркуляції, СКВ - середнє квадратичне відхилення реєстрованих допплерівських сигналів та коефіцієнт варіації.

За B.I. Козловим (2012) куляції (ПМ) являє собою інтегральну характеристику кровотоку, який є функцією від середньої швидкості руху еритроцитів (Vcep.), показника капілярного гематокриту (Htk) і числа функціонуючих капілярів у вимірюваному об’ ємі тканин (Nk):

$$
\Pi \mathrm{M}=\mathrm{V} \text { cep } . \times \mathrm{Htk} \times \mathrm{Nk}
$$

ПМ вимірюється в умовних одиницях і характеризує величину перфузії кров'ю одиниці об'єму тканини за одиницю часу.

Параметр $\sigma$ (СКВ) - середнє коливання перфузії щодо середнього значення потоку крові М. СКВ обчислюється за формулою для середньоквадратичного відхилення ${ }^{6,7,9}$. Має розмірність у перфузних одиницях.
Також під час аналізу розрахункових параметрів доцільно орієнтуватися на співвідношення величин ПМ та СКВ, тобто на коефіцієнт варіації:

$$
K v=\frac{C K B}{\Pi M} \cdot 100
$$

Важливим етапом ЛДФ-метрії $є$ амплітудно-частотний аналіз (АЧС) гемодинамічних ритмів коливань тканинного кровотоку. АЧС-аналіз проводився за допомогою спеціального розщеплення ЛДФ-грами на гармонійні складники, у разі якого з'являється можливість визначити ступінь вираження або домінування тих чи інших коливань тканинного кровотоку в тканинній гемодинаміці. Програмне забезпечення грунтувалося на спектральному розщепленні ЛДФ-грами 3 використанням математичного апарата Фур' $\epsilon^{10,11}$. Амплітуда кожної гармоніки визначалася в діапазоні частот від 0,01 до 1,2 Гц.

У разі амплітудно-частотного аналізу ЛДФ-грами вираховувались амплітуда (А) міогенних метаболічних коливань у діапазоні частот від 0,01 до 0,03 Гц (1-2 коливання за хвилину) (AVLF); вазомоторних коливань у діапазоні частот від 0,05 до 0,15 Гц (4-8 коливань за хвилину) (ALF); дихальних коливань у діапазоні частот від 0,2 до 0,3 Гц (AHF) і пульсових хвиль (ACF). Внесок різноманітних ритмічних складників (Р) оцінюється за їх потужністю у відсотковому відношенні до загальної потужності спектра флаксмоцій ${ }^{5,7,12}$ :

$\mathrm{P}=\mathrm{ALF} 2 /(\mathrm{AVLF} 2+\mathrm{ALF} 2+\mathrm{AHF} 2+\mathrm{ACF} 2) \times 100 \%$.

Аналіз кількісних показників проведено 3 використанням статистичної програми Microsoft Excel з визначенням середніх значень (M), середнього квадратичного відхилення $(\sigma)$, середньої помилки (m).

\section{Результати}

На окремих стадіях постнатального онтогенезу система мікроциркуляції крові має різні характеристики. За нашими даними, в ході онтогенезу від 14 до 19 років у хлопчиків і дівчат триває формування системи мікроциркуляції крові і перебудова механізмів регуляції.

Так, було визначено, що показники параметру мікроциркуляції крові (ПМ) змінюються від порівняно низьких значень у пубертатному до високих показників у постпубертатному віці (таблиці 1 та 2).

У пубертатний період онтогенезу у хлопчиків-підлітків 14-15 років параметр мікроциркуляції крові не перевищував $6,7 \pm 0,4$ перф. од., величина СКВ не перевищувала $0,78 \pm 0,11$ перф. од., а показник інтенсивності кровотоку у середньому дорівнював $1,52 \pm 0,15$ ум. од.

На відміну від хлопчиків, у дівчат-підлітків у 14-15 років реєструвався більш швидкий 
темп показників мікроциркуляції крові: параметр мікроциркуляції у середньому дорівнював

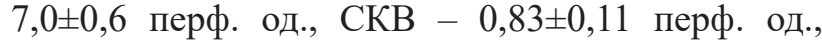
ІФМ - 1,64 $\pm 0,15$ ум. од.

У постпубертатний період онтогенезу (18-19 років) темпи приросту показників у групі юнаків підвищувалися до $8,1 \pm 0,7$ перф.

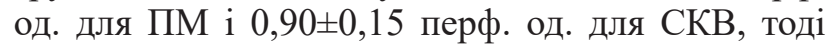
як серед дівчат цього віку ПМ збільшувався до

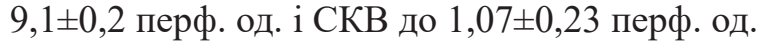

Також простежували, що у досліджуваних осіб зберігається гетерохронність по величинах показників ПМ і СКВ (таблиця 3).

Серед амплітудних характеристик показник низькочастотних вазомоторних коливань був максимальний у 18-19 років як серед юнаків, так і дівчат. У постпубертатному періоді у дівчат та юнаків має місце слабке зниження амплітуди високочастотного ритму.

Виходячи 3 якісного аналізу допплерограм було виділено три типи, які суттєво відрізнялися за своїми параметрами та відповідали певним типам мікроциркуляції крові: аперіодична ЛДФграма (I тип), монотонна висококоамплітудна ЛДФ-грама (II тип), монотонна низькоамплітудна ЛДФ-грама (III тип) (таблиця 4).
Складний коливальний процес, графічно представлений у вигляді аперіодичного типу ЛДФ-грам (рис. 1), відображає зміни концентрації і швидкості потоку еритроцитів. Для аперіодичних ЛДФ-грам характерні відносно

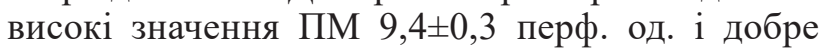
виражені аперіодичні коливання кровотоку СКВ - 1,01 $\pm 0,12$ перф. од.

Тимчасова мінливість кровотоку є об'єктивною характеристикою рівня життєдіяльності тканин i виступає як суперпозиція «активних» i «пасивних» модуляцій флаксмоцій. Активні модуляції перебувають під контролем міогенного та нейрогенного механізмів і характеризуються величиною амплітуди й потужності спектра VLF і LF-коливань.

У частотно-амплітудному спектрі ЛДФ-грам I типу домінують дуже низькочастотні коливання 3 частотою менше 0,03 Гц (VLF-коливання) і низькочастотні вазомоторні в діапазоні 0,05-0,15 Гц (LF-коливання).

Переважання амплітуди низькочастотних коливань над високочастотними ритмами в частотно-амплітудному спектрі ЛДФ-грам I типу відображає максимально висока величина ІФМ $1,89 \pm 0,23$ ум. од.

Таблиця 1 - Динаміка показників мікроциркуляції крові за даними ЛДФ у досліджуваних жіночої статі різного віку

\begin{tabular}{|c|c|c|c|c|c|c|c|}
\hline \multirow{2}{*}{ 象气 } & \multirow{2}{*}{$\begin{array}{c}\text { ПМ, } \\
\text { перф. од. }\end{array}$} & \multirow{2}{*}{$\begin{array}{c}\text { СКВ, } \\
\text { перф. од. }\end{array}$} & \multirow{2}{*}{$\begin{array}{c}\text { ІФМ, } \\
\text { ум. од. }\end{array}$} & \multicolumn{4}{|c|}{ Амплітуда коливань, перф. од. } \\
\hline & & & & VLF & LF & HF & $\mathbf{C F}$ \\
\hline 14 & $7,2 \pm 0,6$ & $0,82 \pm 0,11$ & $1,62 \pm 0,14$ & $\begin{array}{c}1,60 \pm \\
0,53\end{array}$ & $1,12 \pm 0,16$ & $\begin{array}{c}\mathbf{0 , 3 1 \pm} \\
\mathbf{0 , 0 3}\end{array}$ & $\begin{array}{c}\mathbf{0 , 0 4 \pm} \\
\mathbf{0 , 0 1}\end{array}$ \\
\hline 15 & $6,8 \pm 0,5$ & $0,84 \pm 0,14$ & $1,66 \pm 0,15$ & $\begin{array}{c}1,59 \pm \\
0,33\end{array}$ & $\begin{array}{c}0,93 \pm \\
0,19\end{array}$ & $0,25 \pm 0,02$ & $\begin{array}{c}0,03 \pm \\
0,01\end{array}$ \\
\hline 18 & $9,0 \pm 0,8$ & $1,07 \pm 0,17$ & $1,72 \pm 0,13$ & $\begin{array}{c}2,18 \pm \\
0,64\end{array}$ & $\begin{array}{c}1,44 \pm \\
0,22\end{array}$ & $0,28 \pm 0,02$ & $\begin{array}{c}0,04 \pm \\
0,01\end{array}$ \\
\hline 19 & $9,1 \pm 0,2$ & $1,07 \pm 0,23$ & $1,71 \pm 0,15$ & $\begin{array}{c}2,17 \pm \\
0,24\end{array}$ & $\begin{array}{c}1,41 \pm \\
0,19\end{array}$ & $0,28 \pm 0,03$ & $\begin{array}{c}0,04 \pm \\
0,01\end{array}$ \\
\hline
\end{tabular}

Таблиця 2 - Динаміка показників мікроциркуляції крові за даними ЛДФ у досліджуваних чоловічої статі різного віку

\begin{tabular}{|c|c|c|c|c|c|c|c|}
\hline \multirow{2}{*}{ 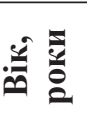 } & \multirow{2}{*}{$\begin{array}{c}\text { ПМ, } \\
\text { перф. од. }\end{array}$} & \multirow{2}{*}{$\begin{array}{c}\text { СКВ, } \\
\text { перф. од. }\end{array}$} & \multirow{2}{*}{$\begin{array}{c}\text { ІФМ, } \\
\text { ум. од. }\end{array}$} & \multicolumn{4}{|c|}{ Амплітуда коливань, перф. од. } \\
\hline & & & & VLF & LF & HF & $\mathbf{C F}$ \\
\hline 14 & $6,0 \pm 0,5$ & $0,74 \pm 0,12$ & $1,50 \pm 0,13$ & $1,47 \pm 0,36$ & $0,91 \pm 0,15$ & $0,30 \pm 0,03$ & $0,05 \pm 0,01$ \\
\hline 15 & $6,5 \pm 0,5$ & $0,77 \pm 0,12$ & $1,54 \pm 0,12$ & $1,42 \pm 0,34$ & $1,05 \pm 0,15$ & $0,27 \pm 0,03$ & $0,03 \pm 0,01$ \\
\hline 18 & $8,0 \pm 0,7$ & $0,90 \pm 0,15$ & $1,70 \pm 0,14$ & $1,95 \pm 0,46$ & $1,38 \pm 0,24$ & $0,26 \pm 0,02$ & $0,02 \pm 0,002$ \\
\hline 19 & $8,1 \pm 0,7$ & $0,90 \pm 0,13$ & $1,72 \pm 0,13$ & $1,95 \pm 0,26$ & $1,37 \pm 0,14$ & $0,26 \pm 0,03$ & $0,02 \pm 0,003$ \\
\hline
\end{tabular}

Таблиця 3 - Основні показники мікроциркуляції крові у дівчат і хлопців на окремих етапах онтогенезу

\begin{tabular}{|c|c|c|c|c|}
\hline \multirow{2}{*}{ Віковий період } & \multicolumn{2}{|c|}{ Дівчата } & \multicolumn{2}{|c|}{ Хлопці } \\
\cline { 2 - 5 } & $\begin{array}{c}\text { ПМ, } \\
\text { перф. од. }\end{array}$ & $\begin{array}{c}\text { СКВ, } \\
\text { перф. од. }\end{array}$ & $\begin{array}{c}\text { ПМ, } \\
\text { перф. од. }\end{array}$ & $\begin{array}{c}\text { СКВ, } \\
\text { перф. од. }\end{array}$ \\
\hline Пубертатний & $7,0 \pm 0,6$ & $0,83 \pm 0,11$ & $6,7 \pm 0,4$ & $0,78 \pm 0,11$ \\
\hline Постпубертатний & $9,1 \pm 0,2$ & $1,07 \pm 0,23$ & $8,1 \pm 0,7$ & $0,90 \pm 0,15$ \\
\hline
\end{tabular}


Таблиця 4 - Середні параметри різних типів ЛДФ-грам

\begin{tabular}{|c|c|c|c|c|}
\hline \multicolumn{2}{|c|}{ Параметри } & $\begin{array}{c}\text { Аперіодична } \\
\text { ЛДФ-грама (I тип) }\end{array}$ & $\begin{array}{c}\text { Монотонна } \\
\text { високоамплітудна } \\
\text { ЛДФ-грама (II тип) }\end{array}$ & $\begin{array}{c}\text { Монотонна } \\
\text { низькоамплітудна } \\
\text { ЛДФ-грама (III тип) }\end{array}$ \\
\hline \multirow{3}{*}{\multicolumn{2}{|c|}{$\begin{array}{l}\text { ПМ, перф. од. } \\
\text { СКВ, перф. од. } \\
\text { ІФМ }\end{array}$}} & $9,4 \pm 0,3$ & $18,7 \pm 0,9$ & $5,4 \pm 0,5$ \\
\hline & & $1,01 \pm 0,12$ & $2,01 \pm 0,3$ & $0,55 \pm 0,12$ \\
\hline & & $1,89 \pm 0,23$ & $1,34 \pm 0,06$ & $1,42 \pm 0,09$ \\
\hline \multirow{2}{*}{ VLF } & A*, перф. од. & $2,79 \pm 0,38$ & $1,26 \pm 0,24$ & $1,58 \pm 0,14$ \\
\hline & Внесок $* *, \%$ & $59 \pm 2$ & $48 \pm 3$ & $57 \pm 3$ \\
\hline \multirow{2}{*}{$\mathrm{LF}$} & А, перф. од. & $1,48 \pm 0,16$ & $0,83 \pm 0,15$ & $0,85 \pm 0,19$ \\
\hline & Внесок, \% & $33 \pm 1$ & $31 \pm 1$ & $31 \pm 2$ \\
\hline \multirow{2}{*}{$\mathrm{HF}$} & А, перф. од. & $0,24 \pm 0,03$ & $0,31 \pm 0,07$ & $0,22 \pm 0,02$ \\
\hline & Внесок, \% & $6 \pm 0,5$ & $11 \pm 1$ & $8 \pm 1$ \\
\hline \multirow{2}{*}{$\mathrm{CF}$} & А, перф. ед. & $0,04 \pm 0,003$ & $0,24 \pm 0,05$ & $0,10 \pm 0,004$ \\
\hline & Внесок, \% & $2 \pm 0,2$ & $9 \pm 0,5$ & $4 \pm 0,5$ \\
\hline
\end{tabular}

Примітки: * - амплітуда коливань; ** - внесок у спектральну потужність

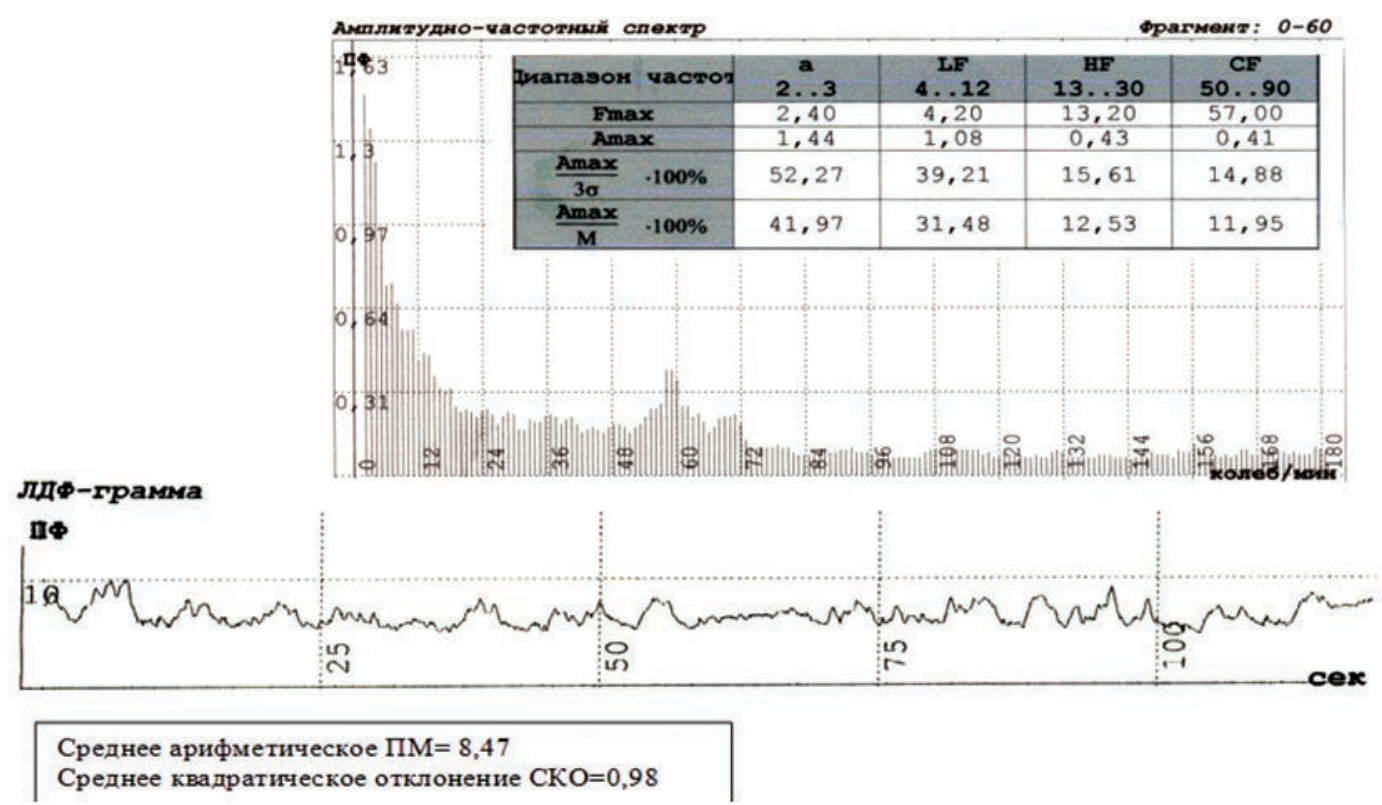

Рис. 1. Аперіодична ЛДФ-грама у досліджуваної дівчини 18-річного віку (I тип)

Таким чином, за характеристиками тканинного кровотоку і збалансованості механізмів активної i пасивної його регуляції аперіодичний тип ЛДФграм відповідає нормоемічному типу мікроциркуляції крові.

Такий тип мікроциркуляції крові зустрічався у 55\% досліджуваних.

Помітно рідше зустрічався II тип ЛДФ-грам (у 8\% випадків) (рис. 2). Досліджувані 3 монотонними високоамплітудними ЛДФ-грамами відрізнялися максимально високими значеннями

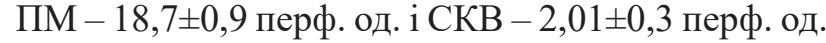
Показники інтенсивності тканинного кровотоку i рівень коливання еритроцитів були вищими.

Зберігаються типологічні особливості і серед показників частотно-амплітудного спектра. Як показують результати дослідження, середня вели- чина амплітуди CF-ритму у монотонного високоамплітудного типу ЛДФ-грам значно вища за показник у аперіодичних ЛДФ-грам і монотонно низькоамплітудного типу.

Домінування пасивних механізмів модуляції тканинного кровотоку проявляється через достовірне зростання амплітуди і потужності спектра HF-коливань, зумовлених роботою «дихального насоса». Місцем локалізації дихальних ритмів у системі мікроциркуляції є венули.

Найбільші зміни стосувалися коливань в області кардіоритму, де амплітуда CF-коливань підвищувалася до 0,24 $\pm 0,05$ перф. од. за одночасного зростання величини спектральної потужності до $9 \pm 0,5 \%$.

Отже, з урахуванням даних частотно-амплітудного спектра у разі монотонного високоамплітуд- 

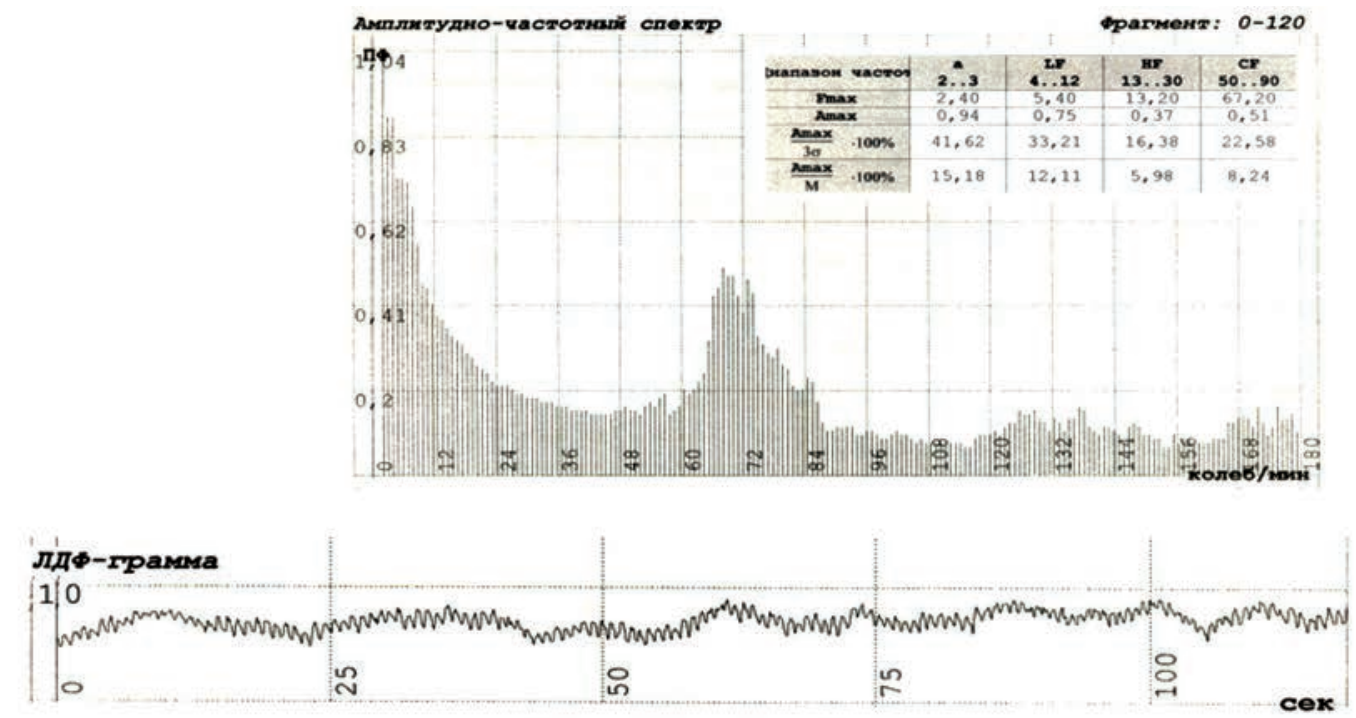

Среднее арифметическое $\Pi \mathrm{M}=9,18$

Среднее квадратическое отклонение СКО $=1,14$

Рис. 2. Монотонна високоамплітудна ЛДФ-грама у юнака 18-річного віку (II тип)

ного типу ЛДФ-грам відбувається не тільки посилення припливу, але і ослаблення відтоку крові з мікроциркуляторного русла, що надалі може ініціювати розвиток застійних процесів.

3 огляду на гіперемічний характер мікроциркуляції, а також зниження внеску вазомоторного ритму в модуляцію тканинного кровотоку, монотонні високоамплітудні ЛДФ-грами відповідають гіперемічному типу мікроциркуляції крові.

Третій тип ЛДФ-грам зустрічався приблизно у кожного третього досліджуваного - в 37\% випадків (рис. 3). Монотонні низькоамплітудні ЛДФграми характеризувалися низькими значеннями

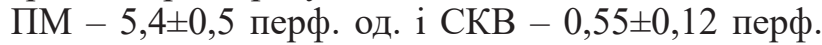
од. Зниження ПМ викликано підвищенням тонусу гладких міоцитів, що регулюють просвіт мікросудин, ланки мікроциркуляторного русла, насамперед прекапілярних артеріол.

Стрімке падіння амплітуди ритмів у низькочастотному спектрі на тлі незмінної величини високочастотних складників призводить до зниження величини ІФМ до 1,42 $\pm 0,09$ ум. од.

Сукупність отриманих параметрів частотно-амплітудного спектра монотонних низькоамплітудних ЛДФ-грам свідчить про формування спрямованості на ослаблення активних у разі одночасного посилення ролі пасивних механізмів у модуляції тканинного кровотоку.

Загалом, монотонний низькоамплітудний тип ЛДФ-грам відповідає гіпоемічному типу мікроциркуляції зі зниженим рівнем перфузії тканин кров'ю і підвищеним тонусом мікросудин, що виникають у результаті підвищення сим- патичних нейрогенних впливів на тканинний кровоток.

Результати дослідження вказують на те, що мають місце відмінності за статевою ознакою показників ЛДФ-грам різних типів.

Найменші відмінності між обстеженими особами чоловічої та жіночої статі виявлені для ЛДФграм аперіодичного типу. За величиною інтенсивності мікроциркуляції і рівнем коливання потоку еритроцитів жіночий організм поступається чоловічому. Так, у дівчат з I типом ЛДФ-грам величина показника ПМ дорівнювала $8,3 \pm 0,8$ перф. од., а

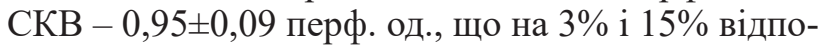
відно менше порівняно з юнаками.

У групі осіб з монотонними низькоамплітудними ЛДФ-грамами відмінності за вивченими показниками посилюються. Дівчата випереджають юнаків за величиною інтенсивності кровотоку на $21 \%$, а за рівнем флаксмоцій - на $11 \%$. У досліджуваних осіб чоловічої статі з монотонними високоамплітудними ЛДФ-грамами величина ПМ на $10 \%$, а СКВ на $14 \%$ більше порівняно 3 показниками у представниць жіночої статі.

У представників 3 аперіодичним типом ЛДФграм з віком підвищується величина інтенсивності кровотоку і рівень його мінливості. Так, у підлітковому віці рівень інтенсивності мікроци-

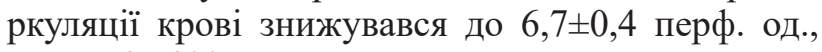
що на $27,2 \%$ нижче середньогрупових значень у юнацькому віці (9,2 $\pm 0,2$ перф. од.) (таблиця 5).

Отже, у досліджуваних осіб з аперіодичним типом ЛДФ-грам у процесі росту і розвитку організму підвищується внесок активних механізмів 
модуляції тканинного кровотоку. Одночасно відбувається підвищення амплітуди респіраторних коливань. Зниження активності міогенного контуру регуляції призводить до збільшення об'єму крові у венулярній ланці і погіршення його відтоку. За принципом зворотного зв'язку ця обставина призводить до посилення дії «дихального насоса» і зростанню амплітуди HF-хвиль.

У підлітків показники спектральної потужності змінюються: 3 одного боку, за рахунок зниження частки дуже низькочастотних (VLF) і низькочастотних (LF) коливань, а 3 іншого - підвищення спектральної потужності високочастотних (HF) i коливань в області кардіоритму (CF). Загалом, до юнацького віку формується дефінітивний рівень співвідношення активних і пасивних механізмів 3 домінуванням активної компоненти модуляції тканинного кровотоку.

У обстежених осіб з монотонними низькоамплітудними ЛДФ-грамами показник параметру мікроциркуляції крові був вищим у досліджуваних

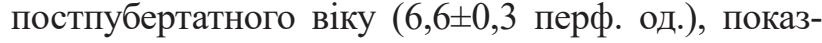
ник рівня флаксмоцій (ІФМ) підвищувався у групі підлітків $(3,01 \pm 0,24)$, а величина СКВ істотно не змінювалася у двох вікових періодах (таблиця 6).

Монотонний високоамплітудний тип ЛДФграм зустрічався в юнацькому віці, за винятком поодиноких випадків серед осіб пубертатного віку, що ускладнює можливість порівняння параметрів ЛДФ-метрії цих двох вікових періодів.

Розподіл різних типів ЛДФ-грам на різних етапах постнатального онтогенезу показав, що серед дівчат-підлітків аперіодичний тип реєструвався у $42 \%$, а монотонний низькоамплітудний - у $55 \%$, $3 \%$ обстежених дівчат мали монотонний високоамплітудний тип ЛДФ-грам. Для хлопчиків-підлітків у $42 \%$ випадків характерний аперіодичний тип і в $56 \%$ - монотонний низькоамплітудний. У $2 \%$ підлітків зустрічався монотонний високоамплітудний тип ЛДФ-грам.

У постпубертатному віці частота вияву ЛДФграм аперіодичного типу зберігається на досить високому рівні і становить 55\% для дівчат і 54\% для юнаків. У дівчат 18-19-річного віку рідше (38\%) зустрічаються монотонні низькоамплітудні ЛДФ-грами і одночасно зростає до 7\% число

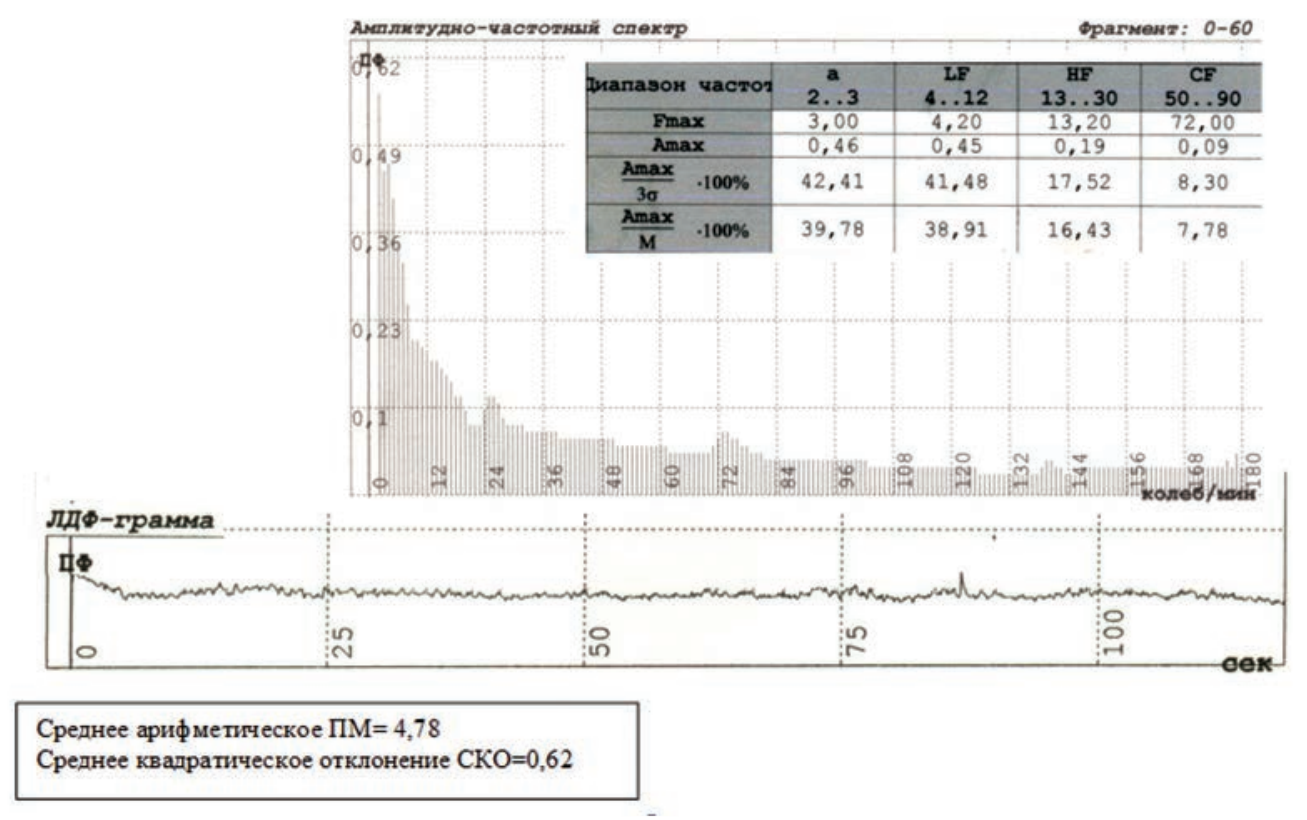

Рис. 3. Монотонна низькоамплітудна ЛДФ-грама у хлопчика 15-річного віку (III тип)

Таблиця 5 - Вікова динаміка параметрів тканинного кровотоку у досліджуваних 3 аперіодичним типом ЛДФ-грам

\begin{tabular}{|c|c|c|}
\hline $\begin{array}{c}\text { Параметри } \\
\text { тканинного } \\
\text { кровотоку }\end{array}$ & $\begin{array}{c}\text { Пубертатний } \\
\text { вік }\end{array}$ & $\begin{array}{c}\text { Постпубертатний } \\
\text { вік }\end{array}$ \\
\hline ПМ, перф. од. & $6,7 \pm 0,4$ & $9,2 \pm 0,2$ \\
\hline СКВ, перф. од. & $1,1 \pm 0,23$ & $0,98 \pm 0,12$ \\
\hline ІФМ ум. од. & $4,47 \pm 0,37$ & $5,39 \pm 0,42$ \\
\hline
\end{tabular}

Таблиця 6 - Вікова динаміка параметрів у досліджуваних з монотонним низькоамплітудним типом ЛДФ-грам

\begin{tabular}{|c|c|c|}
\hline Параметри & $\begin{array}{c}\text { Пубертатний } \\
\text { вік }\end{array}$ & $\begin{array}{c}\text { Постпубертатний } \\
\text { вік }\end{array}$ \\
\hline ПМ, перф. од. & $6,2 \pm 0,4$ & $6,6 \pm 0,3$ \\
\hline СКВ, перф. од. & $0,68 \pm 0,14$ & $0,71 \pm 0,05$ \\
\hline ІФМ ум. од. & $3,01 \pm 0,24$ & $2,27 \pm 0,27$ \\
\hline
\end{tabular}



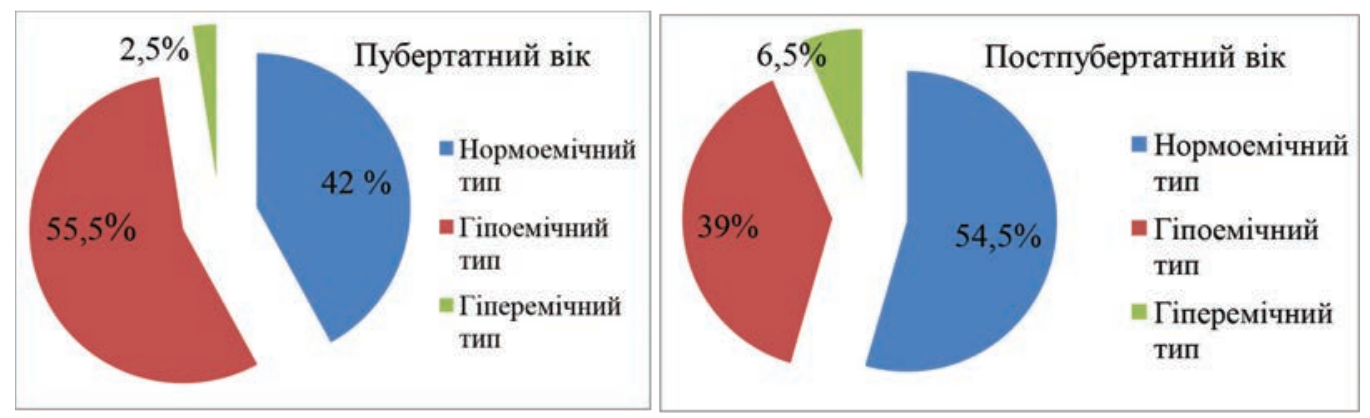

Рис. 4. Розподіл типів мікроциркуляції крові у пубертатний та постпубертатний періоди онтогенезу (\%)

досліджуваних 3 монотонним високоамплітудним типом. У групі юнаків 18-19-річного віку монотонний низькоамплітудний тип реєструвався в $40 \%$, а монотонний високоамплітудний у $6 \%$ випадків від усієї вибірки.

Отримані нами дані вказують на те, що частота співвідношення різних мікроциркуляторних типів приблизно однакова у осіб жіночої та чоловічої статей і безпосередньо залежить від їхнього віку (рис. 4).

\section{Обговорення}

Таким чином, як показали результати дослідження, показники мікроциркуляції крові плавно підвищуються починаючи 3 15-річного віку 3 досягненням максимальної величини у 19 років. Також у досліджуваних осіб зберігається гетерохронність по величинах показників мікроциркуляції крові. Так, в одному віковому періоді вищі показники спостерігалися у досліджуваних дівчат, а в іншому - в юнаків. Це відповідає віковій закономірності гетерохронного дозрівання чоловічого і жіночого організму в онтогенезі, в тому числі і системи мікроциркуляції крові.

Всесвітня практика дослідження кровообігу будується на основі вивчення показників мікроциркуляції крові у разі патологічних процесів у клініці. Тому що будь-яка зміна в організмі веде до порушення траскапілярного обміну.

Серед українських науковців досить поширені дослідження мікроциркуляції крові у разі патологій: у хворих на облітеруючий атеросклероз судин нижніх кінцівок (О. А. Тютюннік, 2007), розладів у печінковому кровоносному руслі (С. І. Шоріков, 2000; С. В. Швець, 2001; А. Р. Сапожніков, 2002), у хворих на нестабільну стенокардію (Н. М. Сидорова, 2003), на гіпертонічну хворобу (В. П. Чижова, 2005; Л. О. Павленко, 2010) та ін.

Індивідуально-типологічні особливості мікроциркуляції крові у здорових людей у процесі онтогенезу вивчаються В. І. Козловим ${ }^{1,}$, 11 , Ф. Б. Литвином ${ }^{4}$, О. А. Гуровою ${ }^{3}$, В. В. Сидоровим ${ }^{13}$ та іншими. В їхніх роботах фундаментально викладені індивідуально-типологічні особливості мікроциркуляції у дітей, підлітків і юнаків, функціональна перебудова мікроциркуляторного русла в процесі онтогенезу, особливості резерву капілярного кровотоку у разі проведення різних функціональних проб у спортсменів ${ }^{12,13}$.

Незважаючи на великий інтерес i актуальність вивчення гемодинамічних процесів, натепер питання про особливості мікроциркуляції крові у здорових людей не розкривається настільки широко, як у клінічних діагностиках ${ }^{8,14}$. Натепер відсутні нормативні показники параметрів тканинного кровотоку у здорових людей у разі використання методу ЛДФ. Тому метою нашої роботи було визначення особливостей мікроциркуляції крові у молодих людей на різних етапах онтогенезу.

\section{Висновки}

В осіб чоловічої та жіночої статей на вивченому етапі онтогенезу зберігається гетерохронність за величинами параметрів мікроциркуляції крові та середнього квадратичного відхилення тканинного кровотоку, коли на одному віковому відрізку вищі показники у досліджуваних жіночої статі, а на іншому - в осіб чоловічої статі. Середні величини показників мікроциркуляції крові у хлопців та дівчат одного віку істотно не відрізнялися.

В обстежених пубертатного та постпубертатного віку обох статей виявлено три типи мікроциркуляції. Аперіодична ЛДФ-грама відповідала нормоемічному типу мікроциркуляції крові, що характеризується збалансованістю механізмів вазомоторної, метаболічної та нейрогенної регуляції мікроциркуляції за частотою і амплітудою. Для синусоїдальної ЛДФ-грами, що відповідає гіпоемічному типу мікроциркуляції крові, характерний низький показник параметру мікроциркуляції, зумовлений зниженням вазомоторних механізмів у регуляції. Монотонна ЛДФ-грама гіперемічного типу характеризувалася високим параметром мікроциркуляції, переважанням пасивних механізмів, дихальних і серцевих ритмів у регуляції мікроциркуляції.

Отримані дані про морфо-функціональні закономірності перетворення системи мікроциркуляції 
крові на етапах статевого дозрівання організму мають принципове значення для розуміння механізмів онтогенезу і роблять істотний внесок у фундаментальні біологічні знання. Обгрунтовані в результаті дослідження вікові нормативні показники стану мікроциркуляції крові у підлітків і досліджуваних юнацького віку суттєво полегшують виявлення функціональних станів їхнього організму 3 вико- ристанням сучасних неінвазивних методів діагностики. Описані механізми активних і пасивних модуляцій тканинного кровотоку, що супроводжуються дисбалансом активності симпатичного і парасимпатичного відділів вегетативної нервової системи i можуть стати фізіологічним обгрунтуванням застосування методу ЛДФ-метрії у діагностиці розладів системи мікроциркуляції крові.

\section{Література}

(1) Козлов, В. И. Развитие системы микроциркуляции; РУДН: Москва, 2012; 314 с.

(2) Тихомирова, И. А.; Бабошина, Н. В.; Терехин, С. С. Возможности метода лазерной допплеровской флуометрии в оценке возрастных особенностей функционирования системы микроциркуляции. Регионарное кровообращение и микроциркулящия. 2018; № 17(3), с. 80-86. DOI: $10.24884 / 1682-6655-2018-17-3-80-86$.

(3) Гурова, О. А. Индивидуально-типологические особенности микроциркуляции крови у детей. Новые исследования. 2014; № 2(39), с. 15-23.

(4) Литвин, Ф. Б. Возрастные и индивидуально-типологические особенности микроциркуляции у мальчиков-подростков и юношей. Регионарное кровообращение и микроциркуляция. 2006; T. 5 , с. $44-50$.

(5) Козлов, В. И.; Азизов, Г. А. Лазерная допплеровская флоуметрия в оиенке состояния и расстройств микроциркулящии крови; РУДН ГНЦ лазер. мед.: Москва, 2012; 32 с.

(6) Крупаткин, А. И.; Сидоров, В. В. Лазерная допплеровская флоуметрия микроциркуляции крови; Изд-во «Медицина»: Москва, 2005; 254 с.

(7) Крупаткин, А. И.; Сидоров, В. В. Функииональная диагностика состояния микроциркуляторно-тканевых систем: колебания, информаиия, нелинейность; Книжный дом «ЛИБРОКОМ»: Москва, 2013; 496 с.

(8) Станішевська, Т. І.; Горна, О. І.; Горбань, Д. Д. Суточная динамика показателей микроциркуляции крови у девушек-студенток. Педагогіка, психологія та медико-біологічні проблеми фізичного виховання і спорту. 2015; № 6, с. 23-29. DOI: http://doi.org/10.15561/18189172.2015.0604.

(9) Lenasi, H. Assessment of Human Skin Microcirculation and Its Endothelial Function Using Laser Doppler Flowmetry. Science, Technology and Medicine open access content. 2011; 13, 271-296. DOI: http://doi.org/10.5772/27067.

(10) Osadchyi, V. V.; Stanishevska, T. I.; Gorna, O. I. Method of using laser doppler flowmetry in assessment of the state of blood microcirculation system. Optical Fibers and Their Applications. 2020; V. 11456. DOI: ttps://doi.org/10.1117/12.2569778.

(11) Kozlov, I. O.; Zherebtsov, E. A.; Zherebtsova, A. I.; Dunaev, A. V. The analysis of processing algorithms of laser Doppler signal in LabVIEW software. Symposium Proceedings of 2nd International Scientific Symposium "Sense. Enable. SPITSE". 2015; 225-227.

(12) Lesnyh, A. W.; Shimko, E. A. Measuring of Microcirculation Blood Flow in Capillaries with a LaserDoppler Flowmetry. Izvestiya of Altai State University. 2017; 1 (93), 15-18. DOI: http://doi.org/10.14258/ izvasu(2017)1-024.

(13) Dunaev, A.; Sidorov, V.; Stewart, N.; Sokolovski, S.; Rafailov, E. Laser reflectance oximetry and Doppler flowmetry in assessment of complex physiological parameters of cutaneous blood microcirculation. Progress in Biomedical Optics of SPIE. 2013; 8572, 27-32. DOI: http://doi.org/10.1117/12.2001797.

(14) Станішевська, Т. І.; Горбань, Д. Д.; Денисенко, В. І. Залежність типу мікроциркуляції крові від типу вищої нервової діяльності в студентів. Вісник Запорізького національного університету. Біологічні науки. 2016; № 1, с. 102-109. 